\title{
New imidazolidinic bioisosters: potential candidates for antischistosomal drugs
}

\author{
Maira GR Pitta/ ${ }^{+}$, Andréa CA Silva, Juliana Kelle AL Neves, Poliana G Silva, João I Irmão*, \\ Elizabeth Malagueño**, José V Santana**, Maria CA Lima, Suely L Galdino, Ivan R Pitta, \\ Mônica CPA Albuquerque*/**
}

\begin{abstract}
Departamento de Antibióticos *Departamento de Medicina Tropical **Laboratório de Imunopatologia Keizo Asami, Universidade Federal de Pernambuco, Av. Prof. Moraes Rego s/nº, Cidade Universitária, 50670-901 Recife, PE, Brasil
\end{abstract}

The emergence of strains of Schistosoma resistant to praziquantel has drawn attention to the search for new schistosomacide drugs. Imidazolidinic derivatives have performed outstandingly against adult $\mathrm{S}$. mansoni worms when evaluated in vitro. The molecular modification of imidazolidine by way of bioisosteric replacement gives rise to variations in its biological response. This study verifies the potential of substituent groups in the derivatives (Z)3benzyl-5-(2-fluoro-benzylidene)-imidazolidine-2,4-dione NE4, 3-benzyl-5-(4-chloro-arylazo)-4-thioxo-imidazolidin2-ona PT5, 3-benzyl-5-(3-fluoro-benzylidene)-1-methyl-2-thioxo-imidazolidin-4-one JT53; 3-benzyl-1-methyl-5-(4methyl-benzylidene)-2-thioxo-imidazolidin-4-one JT63; 3-benzyl-1-methyl-5-(4-methoxi-benzylidene)-2-thioxoimidazolidin-4-one JT68; 3-(4-chloro-benzyl)-1-methyl-5-(4-methoxi-benzylidene)-2-thioxo-imidazolidin-4-one JT69; 3-(4-phenyl-benzyl)-1-methyl-5-(4-methoxi-benzylidene)-2-thioxo-imidazolidin-4-one JT72 by determining the viability in vitro of adult $\mathrm{S}$. mansoni worms in the presence of these derivatives. The susceptibility of the worms obtained from mice and kept in culture in the presence of different concentrations was determined by way of schistosomacide kinetic, observed every 24 h over a period of eight days. The results show that the worms were more sensitive to the PT5 derivative at a concentration of $58 \mu \mathrm{M}$ which killed $100 \%$ of the worms after $24 \mathrm{~h}$ of contact, also giving rise to alterations in the tegument surface of the worms with the formation of bubbles and peeling. These observations suggest a strong electronic contribution of the arylazo grouping in the biological response.

Key words: Schistosoma mansoni - imidazolidines - in vitro susceptibility

Schistosomiasis is still a major public health problem in Africa, Eastern Europe, Asia, and South America (WHO 1993). For some species of Schistosoma that infect humans, praziquantel, an isoquinolin-4-one, is the only effective drug (Davis \& Wegner 1979). However, its continuous use for more than 25 years, against infections caused by both cestodes and trematodes, has made the parasites resistant (Silva et al. 2005). At present, various research groups are dedicating themselves to identifying new schistosomacide agents obtained from natural (Hamed \& Hetta 2005, Tallima et al. 2005, Massoud et al. 2005) and synthetic sources (Bahgat et al. 2005, Abass \& Mostafa 2005).

The imidazolidines are a broad class of bioactive compounds that also have schistosomacide properties. Niridazol, 1-(5-nitro-thiazol-2-yl)-imidazolidin-2-one, the drug used in the last century, has been widely used for clinical purposes (Cioli et al. 1995).

The schistosomacide properties of imidazoline derivatives has been shown in the case of adult $S$. mansoni worms in in vitro studies (Oliveira et al. 2004, Albuquer-

Financial support: Finep, CNPq

${ }^{+}$Corresponding author: jcmonica@globo.com

Received 25 May 2006

Accepted 26 June 2006 que et al. 2005). It is known that the structural variations lead to alterations in the physical properties and reactivity of the chemical compounds, thereby giving rise to changes in the distribution in the cells and tissues and in access to the active enzyme and receptor centers. The molecular modification of imidazolidine by bioisosteric replacement produces a biological response. This study evaluated the schistosomacide effect of imidazolidine derivatives with different substituent groups by determining their in vitro viability against adult $S$. mansoni worms.

New 3-benzyl-5-benzylidene-1-methyl-2-thioxoimidazolidine JT derivatives were obtained in four stages. At first, $N$-methyl-glicine or sarcosine reacts with ammonium thiocianate to form 1-methyl-2-thioxo-imidazolidin4-one. At the same time, Cope esters are obtained by the reaction of substituted benzadehydes with ethyl cyanoacetate in the presence of piperidene (Cope et al. 1941). To obtain the intermediary substitutes in position 5 of the 2-thioxo-imidazolidine nucleus, an addition reaction like that of Michael's was used reacting 1-methyl-2-thioxoimidazolidin-4-one with the different Cope esters, to obtain the 5-benzylidene-1-methyl-2-thioxo-imidazolidin-4one derivatives, which react with benzyl bromide to produce the 3-benzyl-5-benzylidene-1-methyl-2-thioxoimidazolidin-4-one derivatives JT.

The synthesis and the physico-chemical properties of the derivatives $(Z) 3$-benzyl-5-(2-fluoro-benzylidene)imidazolidine-2,4-dione NE4 (Lima et al. 1992) and 3-benzyl-5-(4-chloro-arylazo)-4-thioxo-imidazolidin-2-one PT5 
(Brandão et al. 1997) are described in the literature. Crystallographic study of NE4 proved it to have a $Z$ configuration (Simone et al. 1996).

\section{MATERIALS AND METHODS}

The BH strain of $S$. mansoni was kept in the laboratory after it had passed through Biomphalaria glabrata molluscs and Swiss mice (Mus musculus). Mice weighing between 20 and $25 \mathrm{~g}$ were infected by exposure to a cercarian suspension of S. mansoni with approximately 150 cercarias, using the tail immersion technique (Olivier $\&$ Stirewalt 1952).

After seven weeks of infection, the adult $S$. mansoni worms were removed from the mesenteric and portal veins of the infected mice under aseptic conditions (Duvall \& Dewitt 1967). The worms were washed in a RPMI1640 (Sigma) medium kept at pH 7.5 with HEPES $20 \mathrm{mM}$ and supplemented with penicillin $(100 \mathrm{UI} / \mathrm{ml})$, streptomicin $(100 \mu \mathrm{g} / \mathrm{ml})$ and $10 \%$ bovine fetal serum (Cutilab) and transferred to tissue culture plates containing $2 \mathrm{ml}$ of the same medium. Each well received two worms and these were then incubated at $37^{\circ} \mathrm{C}$ in a humid atmosphere containing $5 \% \mathrm{CO}_{2}$

The experiments were approved by the Federal University of Pernambuco's Animal Experiments Ethics Committee, Process no. 185/2004, in accordance with Law 9605 Article 32 Decree 3179 - Art 17.

For the in vitro test with $S$. mansoni, these compounds were dissolved in 1.6\% dimethyl sulphoxide (DMSO) and used in concentrations varying from 29 to $640 \mu \mathrm{M}$, which were added to the medium containing the worms after a period of $2 \mathrm{~h}$ of adaptation to the culture medium. Duplicates were carried out for each concentration used. The parasites were kept for 8 days and monitored every $24 \mathrm{~h}$ to evaluate their general condition: motor activity, alterations in the tegument, mortality rate. The control worms were treated with $1.6 \%$ of DMSO in an RPMI 1640 medium.

\section{RESULTS}

Chemical - In order to obtain the new 3-benzyl-5-benzylidene-1-methyl-2-thioxo-imidazolidin-4-one derivative compounds (JT) 5-benzylidene-1-methyl-2-thioxoimidazolidin-4-one, potassium carbonate as a catalyst and methanol as a solvent were placed in a flask. The reactional mixture was constantly shaken at room temperature for one hour. Subsequently, the substituted benzyl bromide was added. All reactions were accompanied by chromatographic analysis in a thin layer by way of an adequate elution system. The 3-benzyl-5-benzylidene-1-methyl-2thioxo-imidazolidin-4-one derivatives JT were purified by washing with suitable solvents. The fusion points were determined in capillary tubes using a Buchi apparatus. Thin layer chromatography was carried out on Merck 60F254 silicagel chromoplates. The infra-red spectra were produced on $\mathrm{KBr}$ tablets at a concentration of $1 \%$ using a Perkin Elmer 1310 spectrometer. The magnetic nuclear resonance spectra of ${ }^{1} \mathrm{H}$ NMR protons was carried out using a Bruker AC 200 spectrophotometer in DMSO- $\mathrm{d}_{6}$ or $\mathrm{CDCl}_{3}$ as a solvent and the mass spectra using a Delsi-Nermag $\mathrm{R}$ $1010 \mathrm{C}$ spectrometer on electronic impact. 3-benzyl-5-(3-fluoro-benzylidene)-1-methyl-2thioxo-imidazolidin-4-one JT53

$\mathrm{C}_{18} \mathrm{H}_{15} \mathrm{FN}_{2} \mathrm{OS}$ Yield $41 \%$, M.p. $183-184^{\circ} \mathrm{C}, R f$ $\left(\mathrm{CHCl}_{3}: \mathrm{CH}_{3} \mathrm{OH} 8: 2\right) 0,66, \mathrm{IR}(\mathrm{KBr}): v 1680,1460,1570 \mathrm{~cm}^{-}$ ${ }^{1} .{ }^{1} \mathrm{H}$ NMR $\left(\mathrm{DMSO}_{\mathrm{d}}\right): \delta 3.3\left(\mathrm{~s}, 3 \mathrm{H}, \mathrm{NCH}_{3}\right), 4.57(\mathrm{~s}, 2 \mathrm{H}$, $\mathrm{CH}_{2}$ ), $6.82(\mathrm{~s}, 1 \mathrm{H}, \mathrm{CH}), 7.28-7.48$ (m, 5H, benzyl), 7.19-7.26 (m, 1H, benzylidene, 4"), 7.28-7.48 (m, 1H, benzylidene, 5"), 7.87 (d, $1 \mathrm{H}$, benzylidene, 2", $J=7,81), 9.33-9.39(\mathrm{~m}, 1 \mathrm{H}$, benzylidene, 6"). MS $m / z(\%) 326\left(\mathrm{M}^{+} .100\right), 327\left(\mathrm{M}^{+} .+1\right.$ 13.7), $328\left(\mathrm{M}^{+} .+23.38\right), 293(89), 235(12.5), 148(17.1)$.

3-benzyl-1-methyl-5-(4-methyl-benzylidene)-2thioxo-imidazolidin-4-one JT63

$\mathrm{C}_{19} \mathrm{H}_{18} \mathrm{~N}_{2} \mathrm{OS}$ Yield 57\%, M.p. $187-189^{\circ} \mathrm{C}, R f$ $\left(\mathrm{CHCl}_{3}: \mathrm{CH}_{3} \mathrm{OH} 6: 4\right)$ 0,81, IR (KBr): $v 1770,1600,1460 \mathrm{~cm}^{-}$ ${ }^{1} .{ }^{1} \mathrm{H} \mathrm{NMR}\left(\mathrm{CDCl}_{3}\right): \delta 2,39\left(\mathrm{~s}, 3 \mathrm{H}, \mathrm{CH}_{3}\right), 3.28\left(\mathrm{~s}, 3 \mathrm{H}, \mathrm{NCH}_{3}\right)$, $4.62\left(\mathrm{~s}, 2 \mathrm{H}, \mathrm{CH}_{2}\right), 6.4(\mathrm{~s}, 1 \mathrm{H}, \mathrm{CH}), 7.42-7.46(\mathrm{~m}, 2 \mathrm{H}$, benzyl, 2'6'), 7.31-7.35 (m, 3H, benzyl, 3'4' 5'), 7.22 (d, 2H, benzylidene, 3"5" $J=8.1 \mathrm{~Hz}$ ), 8.11 (d, 2H, benzylidene, 2"6" $J=8.1 \mathrm{~Hz})$. MS $m / z(\%) 322\left(\mathrm{M}^{+} .44 .19\right), 323\left(\mathrm{M}^{+} .+110.97\right)$, $324\left(\mathrm{M}^{+} .+21.29\right), 298(24.2), 145(87.7), 130(58.7), 91(100)$, 65(43.2).

3-benzyl-1-methyl-5-(4-methoxi-benzylidene)-2thioxo-imidazolidin-4-one JT68

$\mathrm{C}_{19} \mathrm{H}_{18} \mathrm{~N}_{2} \mathrm{O}_{2} \mathrm{~S}$ Yield $56 \%$, M.p. $178-180^{\circ} \mathrm{C}, R f$ $\left(\mathrm{CHCl}_{3}: \mathrm{CH}_{3} \mathrm{OH} 6: 4\right)$ 0,78, IR (KBr): $v 1680,1590,1460 \mathrm{~cm}^{-}$ ${ }^{1} .{ }^{1} \mathrm{H}$ NMR (DMSO-d 6 ): $\delta 3.29\left(\mathrm{~s}, 3 \mathrm{H}, \mathrm{NCH}_{3}\right), 3,81(\mathrm{~s}, 3 \mathrm{H}$, $\left.\mathrm{OCH}_{3}\right), 4.58\left(\mathrm{~s}, 2 \mathrm{H}, \mathrm{CH}_{2}\right), 6.79(\mathrm{~s}, 1 \mathrm{H}, \mathrm{CH}), 7.29-7.48(\mathrm{~m}, 3 \mathrm{H}$, benzyl, 3'4' 5'), 7.45-7.48 (m, 2H, benzyl, 2'6'), 6.99 (d, 2H, benzylidene, 3" $5 " J=8.6 \mathrm{~Hz}), 8.32$ (d, 2H, benzylidene, 2"6" $J=8.6 \mathrm{~Hz})$. MS $m / z(\%) 338\left(\mathrm{M}^{+} .21 .64\right), 339\left(\mathrm{M}^{+} .+13.18\right)$, $340\left(\mathrm{M}^{+} .+20.32\right), 305(8.6), 161(31.9), 146(100), 91(41.8)$, 65(17.3).

3-(4-chloro-benzyl)-1-methyl-5-(4-methoxi-benzylidene)-2-thioxo-imidazolidin-4-one JT69

$\mathrm{C}_{19} \mathrm{H}_{17} \mathrm{ClN}_{2} \mathrm{O}_{2} \mathrm{~S}$ Yield 53\%, M.p.. 219-219 ${ }^{\circ} \mathrm{C}, R f$ $\left(\mathrm{CHCl}_{3}: \mathrm{CH}_{3} \mathrm{OH} 6: 4\right)$ 0,82, IR (KBr): $v 1670,1590,1460 \mathrm{~cm}^{-}$ ${ }^{1} .{ }^{1} \mathrm{HNMR}\left(\mathrm{CDCl}_{3}\right): \delta 3.28\left(\mathrm{~s}, 3 \mathrm{H}, \mathrm{NCH}_{3}\right), 3,86\left(\mathrm{~s}, 3 \mathrm{H}, \mathrm{OCH}_{3}\right)$, $4.57\left(\mathrm{~s}, 2 \mathrm{H}, \mathrm{CH}_{2}\right), 6.39$ (s, $\left.1 \mathrm{H}, \mathrm{CH}\right), 7.29$ (d, 2H, benzyl, 2' 6 ' $J=8.7 \mathrm{~Hz}), 7.29\left(\mathrm{~d}, 2 \mathrm{H}\right.$, benzyl, 3' $\left.5^{\prime} J=8.7 \mathrm{~Hz}\right), 6.88(\mathrm{~d}, 2 \mathrm{H}$, benzylidene, 3"5" $J=8.8 \mathrm{~Hz}), 8.25$ (d, 2H, benzylidene, 2"6" $J=8.8 \mathrm{~Hz})$. MS $m / z(\%) 372\left(\mathrm{M}^{+} .13 .29\right), 373\left(\mathrm{M}^{+} .+13.79\right)$, $374\left(\mathrm{M}^{+} .+26.31\right), 161(22.1), 146(100), 125(43.4), 90(6.5)$, 63(17.8).

3-(4-phenyl-benzyl)-1-methyl-5-(4-methoxi-benzylidene)-2-thioxo-imidazolidin-4-one JT72

$\mathrm{C}_{25} \mathrm{H}_{22} \mathrm{~N}_{2} \mathrm{O}_{2} \mathrm{~S}$ Yield $67 \%$, M.p. $157-159^{\circ} \mathrm{C}, R f$ ( $\left.\mathrm{CHCl}_{3}: \mathrm{CH}_{3} \mathrm{OH} 6: 4\right)$ 0,76, IR (KBr): $v 1670,1590,1450 \mathrm{~cm}^{-}$ ${ }^{1} .{ }^{1} \mathrm{HNMR}\left(\mathrm{CDCl}_{3}\right): \delta 3.21\left(\mathrm{~s}, 3 \mathrm{H}, \mathrm{NCH}_{3}\right), 3,84\left(\mathrm{~s}, 3 \mathrm{H}, \mathrm{OCH}_{3}\right)$, $4.6\left(\mathrm{~s}, 2 \mathrm{H}, \mathrm{CH}_{2}\right), 6.34(\mathrm{~s}, 1 \mathrm{H}, \mathrm{CH}), 7.63-7.65(\mathrm{~m}, 1 \mathrm{H}), 7.25-$ 7.43 (m, $8 \mathrm{H}$, benzyl), 6.92 (d, $2 \mathrm{H}$, benzylidene, $3 " 5 " J=8.8 \mathrm{~Hz}$ ), 8.23 (d, 2H, benzylidene, 2"6" $J=8.8 \mathrm{~Hz})$. MS $m / z$ (\%) 414(M ${ }^{+}$. 30.78), $415\left(\mathrm{M}^{+} .+14.36\right), 167(75.8), 166(49.2), 165(100)$, 161(25.6), 152(40.9), 146(93.2), 91(9.6).

Biological - The evaluation of the in vitro susceptibility of $S$. mansoni to the 2-thioxo-imidazolidin-4-one derivatives JT53, JT63, JT68, JT69, JT72 revealed that the worms were sensitive during the first $24 \mathrm{~h}$ to the compounds JT53, JT63, and JT72, the highest mortality rate 
occurring after $48 \mathrm{~h}$ of contact at a concentration of 644 $\mu \mathrm{M}$. The JT68 and JT69 compounds, at the same concentration, achieved their maximum response after $72 \mathrm{~h}$. The JT53 and JT72 compounds killed around 9 and 16\% of the worms respectively with the lower concentration used. Adult male worms, when submitted to the action of derived arylazo imidazolidine PT5 were shown to be sensitive at all the concentrations used with $100 \%$ mortality after $24 \mathrm{~h}$ of contact. In the case of female worms, a clear relation was observed between the concentration used and the effect after a period of $24 \mathrm{~h}$. The maximum effect achieved, at concentrations of $58 \mu \mathrm{M}$ and $116 \mu \mathrm{M}$, was after 96 and $72 \mathrm{~h}$, respectively. The sensitivity of the adult $S$. mansoni worms to the imidazolidine-2,4-dione derivative NE4 could be seen from the first day of treatment onwards. A maximum response of $100 \%$ mortality was achieved at the end of the fourth day of exposure to the $320 \mathrm{iM}$ concentration (Figure).

In all the experiments, the control group remained viable throughout the observation period, and were submitted only to the vehicle used to dissolve the different compounds.

\section{DISCUSSION}

The mortality kinetic of adult $S$. mansoni worms in the presence of imidazolidine derivatives was used to evaluate the schistosomacide properties of the imidazolidine derivatives studied.

It can be seen from Table that the compound arylazo imidazolidine PT5 caused $100 \%$ mortality of worms at a concentration of $29 \mu \mathrm{M}$ in the course of a period of $24 \mathrm{~h}$ of contact and was the most active compound. The 2-thioxo-
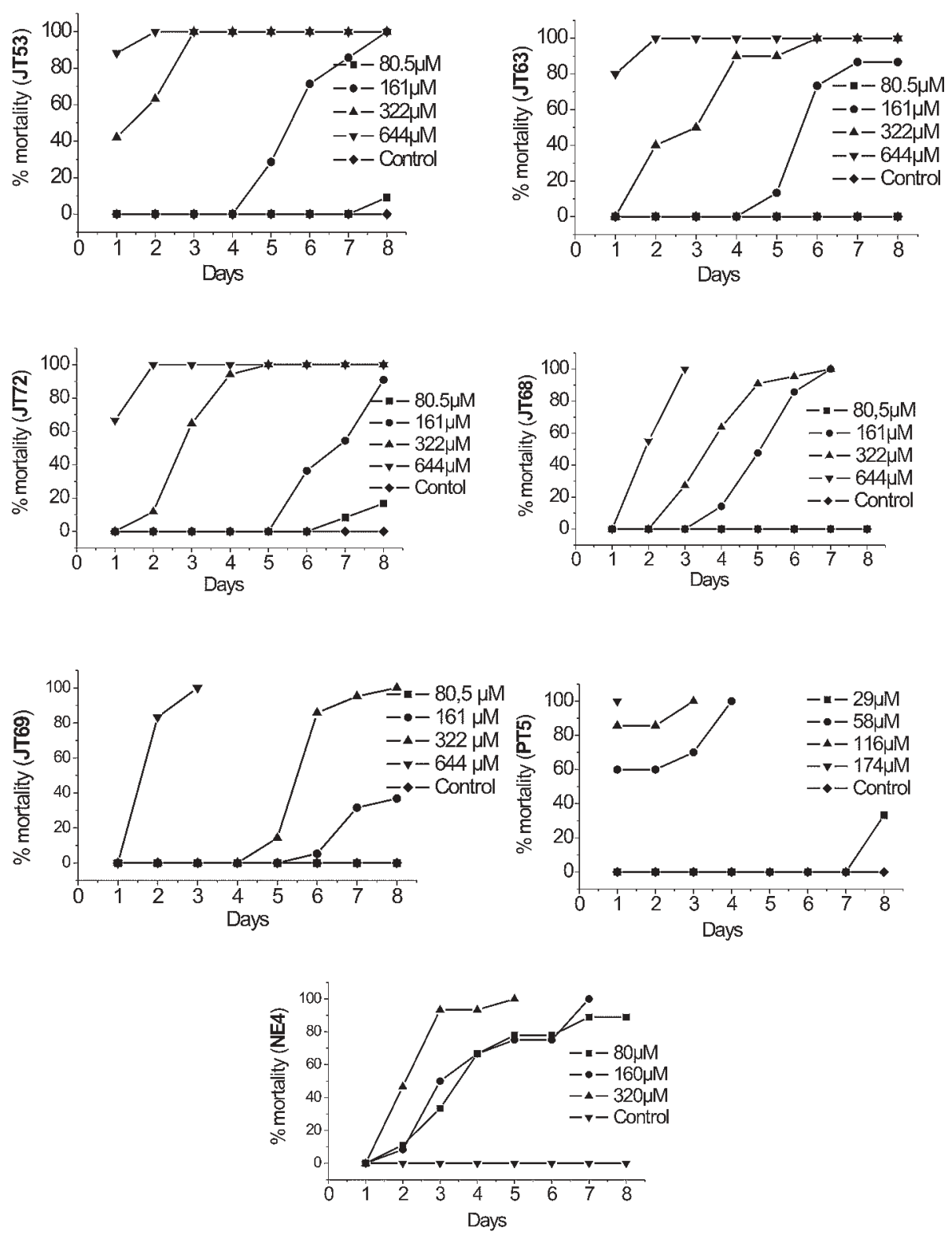

Mortality of adult Schistosoma mansoni worms in the presence of imidazolidine derivatives. 
TABLE

Concentration and contact time capable of producing $100 \%$ mortality of adult Schistosoma worms

\begin{tabular}{lcc}
\hline Compound & Concentration & Contact time (h) \\
\hline JT68 & $640 \mu \mathrm{M}$ & $72 \mathrm{~h}$ \\
JT69 & $640 \mu \mathrm{M}$ & $48 \mathrm{~h}$ \\
JT72 & $640 \mu \mathrm{M}$ & $48 \mathrm{~h}$ \\
JT53 & $640 \mu \mathrm{M}$ & $48 \mathrm{~h}$ \\
JT63 & $640 \mu \mathrm{M}$ & $48 \mathrm{~h}$ \\
NE4 & $320 \mu \mathrm{M}$ & $96 \mathrm{~h}$ \\
PT5 & $174 \mu \mathrm{M}$ & $24 \mathrm{~h}$ \\
\hline
\end{tabular}

imidazolidin-4-one derivatives JT53, JT63, JT68, JT69, and $\mathbf{J T 7 2}$ only reached a similar percentage mortality of worms at a concentration of $644 \mu \mathrm{M}$, after $48 \mathrm{~h}$. The longest period of time taken to cause the death of all the worms was $96 \mathrm{~h}$ of contact at a concentration of $320 \mu \mathrm{M}$ in the case of the NE4 derivative.

All the derivatives studied caused alterations in the tegument surface of the worms with the formation of bubbles and peeling, indicating damage to cells, an effect directly related to the duration of exposure. It was also observed that schistosomacide properties followed a dose-response dependent relation.

The mortality rate and the lesions in the teguments suggest that the imidazolidine derivatives are active against $S$. mansoni. The 3-benzyl-5-(4-chloro-arylazo)-4thioxo-imidazolidin-2-one PT5 derivative proved to be the most active, probably owing to the participation of the arylazo grouping.

\section{REFERENCES}

Abass M, Mostafa BB 2005. Synthesis and evaluation of molluscicidal and larvicidal activities of some novel enaminones derived from 4-hydroxyquinolinones: part IX. Bioorg Med Chem 13: 6133-6144.

Albuquerque MCA, Silva TG, Pitta MGR, Silva ACA, Silva PG, Malagueño E, Santana JV, Wanderley AG, Lima MCA, Galdino SL, Barbe J, Pitta IR 2005. Synthesis and schistosomicidal activity of new substituted thioxoimidazolidine compounds. Pharmazie 60: 13-17.

Bahgat MM, Maghraby AS, Heiba ME, Ruppel A, Fathalla OA 2005. Synthesis of new 4-oxo-2-thioxo-1,2,3,4-tetrahydropyrimidine derivatives with an incorporated thiazolidinone moiety and testing their possible serine protease and cercarial elastase inhibitory effects with a possible prospective to block penetration of Schistosoma mansoni cercariae into the mice skin. Arch Pharm Res 28: 1002-1012.

Brandão SSF, Rocha Filho JA, Chantegrel J, Albuquerque JFC, Ximenes EA, Galdino SL, Pitta IR, Perrissin M, Luu-Duc C 1997. Synthèse et structure des arylazo-imidazolidines et et arylidèneimidazolidines substituées. Ann Pharm
Françaises 55: 206-211.

Cioli D, Pica-Mattoccia L 2003. Praziquantel. Parasitol Res 90: S3-9.

Cioli D, Pica-Mattoccia L, Archer S 1995. Antischistosomal drugs: past, present ... and future? Pharmac \& Ther 68: 3585 .

Cope AC, HofmannCM, Wyckoff C, Hardenber E 1941. Condensation reactions. II. Alkylidene cyanoacetic and malonic ester. J Am Chem Soc 63: 3452-3456.

Davis A, Wegner DH 1979. Multicentre trials of praziquantel in human schistosomiasis: design and techniques. Bull WHO 57: 767-771.

Duvall RH, Dewitt WB 1967. An improved perfusion technique for recovering adult schistosomes from laboratory animals. Am J Trop Med Hyg 16: 483-486.

Hamed MA, Hetta MH 2005. Efficacy of Citrus reticulata and Mirazid in treatment of Schistosoma mansoni. Mem Inst Oswaldo Cruz 100: 771-778.

King CH, Muchiri EM, Ouma JH 2000. Evidence against rapid emergence of praziquantel resistance in Schistosoma haematobium, Kenya. Emerg Infect Dis 6: 585-594.

Lima MCA, Costa DLB, Goes AJS, Galdino SL, Pitta IR, LuuDuc C. 1992. Synthèse et activité antimicrobienne de derives chlorobenzyl benzylidène imidazolidinediones et thiazolidinediones substituées. Pharmazie 47: 182-184.

Massoud AM, el Ebiary FH, Ibrahim SH 2005. Light microscopic study of the effect of new antischistosmal drug (myrrh extract) on the liver of mice. J Egypt Soc Parasitol 35: 971-988.

Oliveira SM, Albuquerque MCPA, Pitta MGR, Malagueño E, Santana JV, Lima MCA, Pitta IR, Galdino SL 2004. A resposta do Schistosoma mansoni mantido in vitro frente a derivados imidazolidinônicos. Acta Farm Bonaerense 23: 343-348.

Oliver L, Stirewalt MA 1952. An efficient method for exposure of mice to cercariae of Schistosoma mansoni. J Parasitol 38: 19-23.

Silva IM, Thiengo R, Conceicao MJ, Rey L, Lenzi HL, Pereira Filho E, Ribeiro PC 2005. Therapeutic failure of praziquantel in the treatment of Schistosoma haematobium infection in Brazilians returning from Africa. Mem Inst Oswaldo Cruz 100: 445-449.

Simone CA, Pereira MA, Luu-Duc C, Pitta IR, Galdino SL, Menezes EHC, Schpector JZ 1996. 3-benzyl-5-(2fluorobenzylidene)-imidazolidine-2,4-dione. Acta Christ 52: 2771-2772

Tallima H, Salah M, El-Ridi R 2005. In vitro and in vivo effects of unsaturated fatty acids on Schistosoma mansoni and $S$. haematobium lung-stage larvae. J Parasitol 91: 1094-1102.

WHO-World Health Organization 1993. WHO Technical Report. The control of schistosomiasis: second report of the WHO Expert Committee. Vol. 830. Geneva. 